\title{
Nutrient and Sediment Discharge from Southern Plains Grasslands
}

\author{
S.J. SMITH, R.G. MENZEL, E.D. RHOADES, J.R. WILLIAMS, AND H.V. ECK
}

\begin{abstract}
Amounts of nitrogen, phosphorus, and sediment were measured in runoff from grassland watersheds in the Blackland Prairies, High Plains, Reddish Prairies, and Rolling Red Plains land resource areas of Oklahoma and Texas. Periods of study were 3 to 5 years and included treatments involving fertilization, cultivation, and burning. Overall nutrient concentrations generally ranged from 2 to $10 \mathrm{mg} / \mathrm{l}$ for nitrogen and 0.3 to $2 \mathrm{mg} / \mathrm{l}$ for phosphorus. In most cases, less than half the nutrients existed as soluble forms in the runoff water. Typically, annual sediment losses were less than 0.5 metric tons/ha. Corresponding losses for nitrogen and phosphorus were less than 5 and $2 \mathrm{~kg} / \mathrm{ha}$, respectively. In the case of nitrate, more was received in precipitation than was lost in runoff. Total nitrogen and phosphorus losses were strongly correlated with sediment losses. Preliminary results using predictive techniques to estimate nutrient and sediment discharge from the watersheds were encouraging. With proper management, the likelihood of any adverse environmental effects due to nutrient and sediment discharge from Southem Plains grasslands appears slight.
\end{abstract}

Increased demand for agricultural products is causing more intensive use of Southern Plains grasslands. Such use includes concentrated grazing, fertilization, and weed/brush control. In addition, a considerable area of marginal land shifts from grassland to cropland and vice-versa depending on wheat and cattle prices. In Oklahoma and Texas, the major portion of the private pasture and rangeland is listed by the Soil Conservation Service as requiring some kind of conservation treatment (USDA 1965). Thus, many of the grasslands are fragile, and studies to assess the potential seriousness of erosion and water quality hazards associated with grassland practices are needed.

Discharge studies of nutrients and sediment from grassland watersheds (Doran et al. 1981, Kilmer 1974, Menzel et al. 1978, Neff 1982, Olness et al. 1975, 1980) can be utilized to (1) evaluate soil fertility losses, (2) determine the effectiveness of management practices for nutrient loss reduction, and (3) assess the environmental impacts of land use. In recent years the Water Quality and Watershed Research Laboratory has conducted a series of cooperative watershed studies across Oklahoma and Texas to assess the impact of various land uses on agricultural water quality. This paper presents an overview of results obtained from grassland watersheds in the Blackland Prairies (BP), High Plains (HP), Reddish Prairies (RP), and the Rolling Red Plains (RRP) land resource areas.

\section{Watersheds}

\section{Study Area and Methods}

Pertinent information about the watersheds is listed in Table 1. They were selected to provide good representation of the land

Authors are soil scientists, retired agricultural engineer, USDA-ARS, P.O. Box 1430. Durant. Okla. 74702: hydraulic engr., USDA-ARS. P.O. Box 748. Temple, Tex. 76503; and soil scientist, USDA-ARS, Drawer 10, Bushland, Tex. 79012, respectively. This manuscript is a contribution from the Southern Region, USDA, Agricultural Research Service.

Technical assistance by D. Meyerhoeffer and W. Lonkerd, USDA-ARS, El Reno, Okla; P. Koshi (retired), and W. Berg. USDA-ARS. Woodward. Okla.; and O. Jones, USDA-ARS, Bushland, Tex. is gratefully acknowledged.

Manuscript received September 27, 1982. resource areas, and encompass a range of soils, slopes, grasses, and treatments. Size of the watersheds varied from 0.04 to 7.9 ha. Periods of study were 3 years for the HP watersheds (1978-80), 5 years (1976-80) for the BP, W-10 watershed, and 4 years (1977-80) for the remainder. Prior to the study, the BP watersheds were in tame pasture or cropland, and all others were in good condition, virgin grassland. Following initiation, grazing intensities varied from none (HP) to double stocking (RP, FR-1). After 2 years, one-half of the RP and RRP watersheds were planted to wheat. Indicated grassland watersheds received specified surface broadcast applications of fertilizer in April. Wheatland watersheds received fertilizer at the fall planting and additional $\mathrm{N}$ applications in late February or early March according to soil tests.

\section{Field Measurement and Sampling}

Because of their small size ( $0.04 \mathrm{ha})$, runoff at the HP watershed outlets was measured with a proportional splitting device. This device collected about one-tenth of the total runoff. At the other watershed outlets runoff was measured using precalibrated flumes or weirs equipped with FW-1 stage recorders. Sediment discharge was determined from suspended sediment concentrations in samples taken automatically before, during, and after runoff peak flow for each event. After comparison with the runoff hydrograph, the samples tor a specific watershed were composited in proportion to total flow to provide a single representative sample of liquid and sediment for chemical analysis. Precipitation was determined from raingages located on or near the watersheds. All runoff and precipitation samples for chemical analysis were refrigerated at 0 to $4^{\circ} \mathrm{C}$ until analyzed. Additional information about the collection and processing procedures is given in Menzel et al. (1978) and Smith et al. (1982).

\section{Laboratory Analyses}

Aliquots of each composited runoff sample were centrifuged and filtered thru $0.45-\mu \mathrm{m}$ Millipore' filters prior to nit rite- $\mathrm{N}$, nit rate- $\mathrm{N}$, ammonium- $\mathrm{N}$, total soluble $\mathrm{P}$, and soluble reactive $\mathrm{P}$ determinations. Total N (TKN) and total P (TP) were determined on the unfiltered composited runoff samples.

Chemical analyses for nitrite- $\mathrm{N}$, nitrate- $\mathrm{N}$, ammonium- $\mathrm{N}$, and TKN were conducted using standard methods as described in the Federal Water Pollution Control Administration manual (USDI 1971). All $P$ determinations were made using the isobutanol extraction method described by Golterman and Clymo (1969). Color was developed by reducing the ammonium molybdate complex with ascorbic acid. Soluble reactive $P$ consisted of all soluble $P$ determined with the molybdate reagent without prior perchloric acid digestion.

The run off events that were sampled and analyzed represent $95 \%$ or more of the runoff during the study period. Nutrient concentrations are reported as flow-weighted means. Nutrient discharges from individual storms were summed to calculate annual discharges.

\section{Results}

Flow-weighted mean nutrient concentrations in runoff from the watersheds are summarized in Table 2. Data are presented for both

ITrade names are included for the benefit of the reader and do not imply endorsement or preferential treatment of the product named by USDA. 
Table 1. Characteristics of the grassland watersheds for various years 1976 through 1980.

\begin{tabular}{|c|c|c|c|c|c|c|c|}
\hline $\begin{array}{l}\text { Resource } \\
\text { area }\end{array}$ & $\begin{array}{l}\text { Water- } \\
\text { shed }\end{array}$ & $\begin{array}{l}\text { Size } \\
\text { (ha) }\end{array}$ & $\begin{array}{l}\text { Approx } \\
\text { slope } \\
(\%)\end{array}$ & $\begin{array}{l}\text { Total } \\
\text { events }\end{array}$ & Major soils & Major grasses & Land use \\
\hline \multirow{3}{*}{$\begin{array}{l}\text { BP } \\
\text { (Riesel, } \\
\text { Tex.) }\end{array}$} & $Y-14$ & 2.2 & 2 & 29 & \multirow[t]{3}{*}{$\begin{array}{l}\text { Houston Black clay } \\
\text { (Udic Pellusterts) }\end{array}$} & Klein (Panicum coloratum) & Moderate graze \\
\hline & $w-10$ & 7.9 & 2 & 19 & & $\begin{array}{l}\text { Coastal bermuda) } \\
\text { (Cynodon dactylon) }\end{array}$ & Moderate graze \\
\hline & SW-11 & 1.1 & 1 & 20 & & $\begin{array}{l}\text { Harding wintergreen } \\
\text { (Phalaris acquatica) }\end{array}$ & Moderate graze \\
\hline \multirow{2}{*}{$\begin{array}{l}\text { HP } \\
\text { (Bushland, } \\
\text { Tex.) }\end{array}$} & N.G. & 0.04 & 1 & 4 & \multirow[t]{2}{*}{$\begin{array}{l}\text { Pullman clay loam } \\
\text { (Torrertic Paleustolls) }\end{array}$} & \multirow{2}{*}{$\begin{array}{l}\text { Blue grama (Bouteloua } \\
\text { gracilis and } \\
\text { Buffalo } \\
\text { (Buchloe dactyloides) }\end{array}$} & Idle \\
\hline & S.G. & 0.04 & 1 & 4 & & & Idle \\
\hline \multirow[t]{8}{*}{$\begin{array}{l}\text { RP } \\
\text { (El Reno. } \\
\text { Okla.) }\end{array}$} & FR-1 & 1.6 & 3 & 12 & \multirow[t]{3}{*}{$\begin{array}{l}\text { Bethany silt loam } \\
\text { (Pachic Paleustolls) }\end{array}$} & $\begin{array}{l}\text { Little bluestem } \\
\text { (Andropogon scoparius) }\end{array}$ & Heavy graze (double stocking) \\
\hline & FR-2 & 1.6 & 3 & 14 & & \multirow{7}{*}{$\begin{array}{l}\text { and } \\
\text { Big bluestem } \\
\text { (Andropogon gerardii) and } \\
\text { Sideoats grama } \\
\text { (Bouteloua curtipendula) }\end{array}$} & Moderate graze/fertilizer ${ }^{2}$ \\
\hline & FR-3 & 1.6 & 3 & 13 & & & Moderate graze \\
\hline & FR-4 & 1.6 & 4 & 13 & $\begin{array}{l}\text { Kirkland silt loam } \\
\text { (Udertic Paleustolls) }\end{array}$ & & $\begin{array}{l}\text { Moderate graze/fertilizer/ } \\
\text { Spring burn }\end{array}$ \\
\hline & FR-5 & 1.6 & 4 & 15 & & & Moderate graze to wheat ${ }^{4}$ \\
\hline & FR-6 & 1.6 & 3 & 15 & & & Moderate graze to wheat ${ }^{4}$ \\
\hline & FR-7 & 1.6 & 3 & 18 & & & Moderate graze to wheat \\
\hline & FR-8 & 1.6 & 3 & 17 & & & Moderate graze to wheat ${ }^{4}$ \\
\hline \multirow{4}{*}{$\begin{array}{l}\text { RRP } \\
\text { (Wood- } \\
\text { ward, Oklia.) }\end{array}$} & WW-1 & 4.7 & 7 & 21 & $\begin{array}{l}\text { Woodward loam } \\
\text { (Typic Ustochrepts) }\end{array}$ & $\begin{array}{l}\text { Sideoats grama } \\
\text { (Bouteloua curtipendula) }\end{array}$ & Moderate graze \\
\hline & WW-2 & 5.5 & 8 & 35 & \multirow{3}{*}{$\begin{array}{l}\text { and } \\
\text { Quinlan loam } \\
\text { (Typic Ustochrepts) }\end{array}$} & \multirow{3}{*}{$\begin{array}{l}\text { and } \\
\text { Hairy grama } \\
\text { (Bouteloua hirsuta) }\end{array}$} & Moderate grazes $^{5}$ \\
\hline & WW-3 & 2.7 & 8 & 22 & & & Moderate graze to wheat ${ }^{6}$ \\
\hline & $W W-4$ & 2.9 & 8 & 27 & & & Moderate graze to wheat ${ }^{6}$ \\
\hline
\end{tabular}

$1160 \mathrm{~kg} \mathrm{~N}$ : ha surface broadcast in 1978.

$256 \mathrm{~kg} \mathrm{~N}$, ha surface broadcast in 1979,$80 ; 22 \mathrm{~kg} \mathrm{P}_{2} \mathrm{O}_{5} /$ ha in 1980.

$356 \mathrm{~kg} \mathrm{~N}$. ha surface broadcast in 1979, 80; $22 \mathrm{~kg} \mathrm{P} \mathrm{P}_{2} \mathrm{O}_{5} /$ ha in 1980.

April burn in 1979 prior to fertilizing. $0.6 \mathrm{~kg} / \mathrm{ha} 2-4 \mathrm{D}$ applied in May, 1980, but not runoff events occurred til following year.

'Planted to wheat since fall 1978. fertilized according to soil test for 40 quintals/ha yield goal.

$538 \mathrm{~kg} \mathrm{~N}$ ha, $22 \mathrm{~kg} \mathrm{P}_{2} \mathrm{O}_{5}$ / ha in 1980; May and Sept. defer grazing.

tPlanted to whet since fall 1979, fertilized according to soil test for 40 quintals/ha yield goal.

unfertilized and fertilized grasslands. For comparative purposes, data for associated recommended-practice croplands (Sharpley et al. 1982) are included. Overall nutrient concentrations generally ranged from 2 to $10 \mathrm{mg} / 1 \mathrm{~N}$ and 0.3 to $2 \mathrm{mg} / 1 \mathrm{P}$. In nearly all cases, less than half the nutrients existed as soluble forms in the runoff water. The RP fertilized grasslands had the highest mean nitrate- $N$ and also ammonium- $\mathrm{N}$ concentrations, 3.2 and $2.6 \mathrm{mg} / 1$, respectively, due to a major runoff event shortly after broadcast application of $56 \mathrm{~kg} \mathrm{~N} / \mathrm{ha}$ as a mmonium nitrate. The relatively high mean ammonium- $\mathrm{N}$ concentrations $(1.23 \mathrm{mg} / \mathrm{l})$ for unfertilized $\mathrm{HP}$ grasslands are attributed to ammonia drift from a nearby cattle feedyard. Highest mean soluble $P$ concentrations $(0.67 \mathrm{mg} / 1)$ resulted also from these ungrazed grasslands, and likely reflect $P$ leaching from dead vegetation.

Highest mean sediment nutrient (TKN and TP) concentrations were about $9 \mathrm{mg} / \mathrm{ITKN}$ for the RRP croplands and $2 \mathrm{mg} / 1 \mathrm{TP}$ for the HP croplands. Generally, the fertilized grasslands and croplands had sediment nutrient concentrations one to several-fold higher than respective unfertilized grasslands.

Annual mean amounts of nutrients discharged from the watersheds are summarized in Table 3. Since the amounts are so low, data for the unfertilized and fertilized grasslands within a land resource area are combined. Nutrient form losses for the grasslands were usually $<1 \mathrm{~kg} / \mathrm{ha}$, and the main differences were the one to several-fold increased sediment nutrient losses (TKN and TP) for the croplands. Such findings are generally consistent with single-season observations (Olness et al. 1975) involving grassland and cropland watersheds in central Oklahoma.

Annual precipitation, runoff, and sediment discharge for the watersheds are summarized in Table 4. Overall, rainfall amounts during the study period were fairly close to the long-term averages. Again, within a land resource area, runoff and sediment discharge for unfertilized and fertilized grasslands were similar, so respective amounts have been combined. For the grasslands, annual runoff ranged from 1 to $14 \mathrm{~cm}$, compared to 4 to $12 \mathrm{~cm}$ for the croplands. The most runoff occurred on the BP watersheds, which are located on the slowly permeable Houston Black clay. Grassland sediment discharge was highest $(787 \mathrm{~kg} / \mathrm{ha}$ ) on the steeper R RP watersheds. As would be expected, annual cropland sediment discharge was considerably higher than the grassland sediment discharge, but none of the croplands yielded more than $3,100 \mathrm{~kg} / \mathrm{ha}$. The SCS tolerable annual soil loss limits for the RRP and other watersheds are approximately 5,550 and $11,100 \mathrm{~kg} / \mathrm{ha}$, respectively ${ }^{2}$. It should be noted that the grassland watersheds in this study were all in good condition prior to initiation of the study. On eroded, continuously grazed watersheds of central Oklahoma, annual sediment discharge as high as $23,000 \mathrm{~kg} / \mathrm{ha}$ as been observed in a wet year (Olness et al. 1975).

\section{Discussion}

Over the relatively short period of this study (3-5 years) specific

2nK and T Factors and Hydrologic Groups of Soils in the South Region" SCS, Still water, OK (File copy dated 10-79). 
Table 2. Flow-weighted mean nutrient concentrations ( $\mathrm{mg} /$ liter) in runoff from representative watersheds.

\begin{tabular}{|c|c|c|c|c|c|c|c|c|c|}
\hline Resource area & No. watersheds & Period & $\mathrm{No}_{2}-\mathrm{N}$ & $\mathrm{NO}_{3}^{-}-\mathrm{N}$ & $\mathrm{NH}_{4}^{+}-\mathrm{N}$ & TKN & TP & Sol. P & React. $\mathbf{P}$ \\
\hline & & \multicolumn{8}{|c|}{ Unfertilized Grasslands } \\
\hline HP & 2 & $1978-80$ & $\begin{array}{l}0.038 \\
(0.063)^{2}\end{array}$ & $\begin{array}{l}0.500 \\
\quad(0.810)\end{array}$ & $\begin{array}{l}1.230 \\
(2.90)\end{array}$ & $\begin{array}{l}4.39 \\
(8.74)\end{array}$ & $\begin{array}{l}0.780 \\
(0.850)\end{array}$ & $\begin{array}{l}0.670 \\
\quad(1.030)\end{array}$ & $\begin{array}{l}0.626 \\
\quad(0.850)\end{array}$ \\
\hline $\mathbf{R P}$ & 2 & $1977-80$ & $\begin{array}{l}0.023 \\
(0.130)\end{array}$ & $\begin{array}{l}0.220 \\
(0.380)\end{array}$ & $\begin{array}{l}0.208 \\
(0.670)\end{array}$ & ${ }_{(2.86)}^{1.66}$ & $\begin{array}{l}0.204 \\
\quad(0.450)\end{array}$ & $\begin{array}{l}0.109 \\
(0.230)\end{array}$ & $\begin{array}{l}0.087 \\
(0.210)\end{array}$ \\
\hline \multirow[t]{2}{*}{ RRP } & 1 & $1977-80$ & $\begin{array}{l}0.015 \\
\quad(0.200)\end{array}$ & $\begin{array}{l}0.213 \\
(0.370)\end{array}$ & $\begin{array}{l}0.210 \\
(0.530)\end{array}$ & $\begin{array}{l}2.80 \\
(15.28)\end{array}$ & $\begin{array}{l}0.764 \\
\quad(9.940)\end{array}$ & $\begin{array}{l}0.174 \\
\quad(0.340)\end{array}$ & $\begin{array}{l}0.158 \\
\quad(0.330)\end{array}$ \\
\hline & \multicolumn{9}{|c|}{ Fertilized Grasslands } \\
\hline BP & 3 & $1976-80$ & $\begin{array}{l}0.214 \\
\quad(5.80)\end{array}$ & $\begin{array}{l}1.474 \\
\quad(13.0)\end{array}$ & $\begin{array}{l}0.647 \\
\quad(14.28)\end{array}$ & 2.67 (24.5) & $\begin{array}{l}0.412 \\
(1.7111)\end{array}$ & $\begin{array}{l}0.082 \\
\quad(0.273)\end{array}$ & $\begin{array}{l}0.073 \\
\quad(0.212)\end{array}$ \\
\hline $\mathbf{R P}$ & 2 & $1979-80$ & $\begin{array}{l}0.028 \\
(0.190)\end{array}$ & $\begin{array}{l}3.18 \\
(11.2)\end{array}$ & 2.59 & $\begin{array}{l}4.00 \\
(8.9)\end{array}$ & $\begin{array}{c}0.448 \\
(2.667)\end{array}$ & $\begin{array}{l}0.339 \\
\quad(1.258)\end{array}$ & $\begin{array}{l}0.301 \\
\quad(1.247)\end{array}$ \\
\hline RRP & 1 & $1979-80$ & $\begin{array}{l}0.009 \\
\quad(0.032)\end{array}$ & $\begin{array}{l}0.249 \\
(1.08)\end{array}$ & $\begin{array}{l}0.147 \\
(1.55)\end{array}$ & $\begin{array}{l}3.70 \\
(7.47)\end{array}$ & $\begin{array}{r}1.700 \\
(4.416)\end{array}$ & $\begin{array}{l}0.128 \\
(0.439)\end{array}$ & $\begin{array}{l}0.105 \\
(0.452)\end{array}$ \\
\hline \multicolumn{10}{|c|}{ Croplands } \\
\hline $\mathbf{B P}^{\prime}$ & 3 & $1976-80$ & $\begin{array}{l}0.082 \\
\quad(1.48)\end{array}$ & $\begin{array}{l}2.67 \\
(28.4)\end{array}$ & $\begin{array}{l}0.081 \\
\quad(0.590)\end{array}$ & $\begin{array}{l}4.73 \\
(20.6)\end{array}$ & ${ }_{(5.514)}^{1.385}$ & $\begin{array}{l}0.052 \\
\quad(0.109)\end{array}$ & $\begin{array}{l}0.050 \\
(0.110)\end{array}$ \\
\hline HPI & 3 & $1978-80$ & $\begin{array}{l}0.042 \\
(0.105)\end{array}$ & $\begin{array}{c}0.553 \\
(5.05)\end{array}$ & $\begin{array}{c}0.108 \\
(0.540)\end{array}$ & $\begin{array}{l}6.38 \\
(17.6)\end{array}$ & $\begin{array}{l}2.085 \\
(6.660)\end{array}$ & $\begin{array}{l}0.138 \\
(0.454)\end{array}$ & $\begin{array}{c}0.123 \\
(0.436)\end{array}$ \\
\hline $\mathbf{R P}$ & 4 & $1979-80$ & $\begin{array}{l}0.099 \\
(0.610)\end{array}$ & $1.84_{(9.23)}$ & $\begin{array}{l}0.549 \\
(14.2)\end{array}$ & ${ }_{(22.1)}^{7.83}$ & $\begin{array}{l}1.648 \\
(9.200)\end{array}$ & $\begin{array}{l}0.309 \\
(7.760)\end{array}$ & $\begin{array}{l}0.291 \\
(2.590)\end{array}$ \\
\hline R RP & 2 & $1977-80$ & $\begin{array}{l}0.014 \\
\quad(0.095)\end{array}$ & $\begin{array}{l}0.266 \\
(9.20)\end{array}$ & $\begin{array}{l}0.335 \\
(5.52)\end{array}$ & ${ }_{(21.6)}^{8.83}$ & $\begin{array}{l}1.553 \\
(4.097)\end{array}$ & $\begin{array}{l}0.120 \\
(1.724)\end{array}$ & $\begin{array}{l}0.104 \\
\quad(1.399)\end{array}$ \\
\hline
\end{tabular}

IBP cropland watersheds are in a cotton-oats-sorghum rotation. HP cropland watersheds a re in a wheat-sorghum-fallow rotation. Additional details about the cropland watersheds are given in Sharpley et al. 1982

2Values in parenthesis are the highest concentrations observed.

water quality effects due to some management factors, such as stocking rates, deferred grazing, herbicide application, and grass species were not evident. This is in agreement with earlier indications (Menzel et al 1978) that many water quality, land-use studies in the Southern Plains a re best designed to operate for long periods
( 10 years or more). In particular, long-term information is needed for testing models to predict watershed behavior regarding nutrient and sediment discharge. Nevertheless, certain important water quality observations are fairly obvious. From an environmental and range management standpoint, discharge of both nut-

Table 3. Mean annual amounts (kg/ha) of nutrient discharge from watersheds.

\begin{tabular}{|c|c|c|c|c|c|c|c|c|c|}
\hline Resource area & No. watersheds & Period & $\mathrm{NO}_{2}^{-}-\mathrm{N}$ & $\mathrm{NO}_{3}^{-}-\mathrm{N}$ & $\mathrm{NH}_{4}^{+}-\mathrm{N}$ & TKN & TP & Sol. P & Reactive $P$ \\
\hline & & & & & \multicolumn{5}{|c|}{ Grasslands } \\
\hline BP & 3 & $1976-80$ & 0.3 & 2.3 & 1.1 & 4.3 & 0.6 & 0.12 & 0.10 \\
\hline HP & 2 & $1978-80$ & 0.0 & 0.1 & 0.1 & 0.5 & 0.1 & 0.08 & 0.07 \\
\hline $\mathbf{R} \mathbf{P}$ & 4 & $1977-80$ & 0.0 & 0.3 & 0.3 & 0.8 & 0.1 & 0.04 & 0.04 \\
\hline RRP & 2 & $1977-80$ & 0.0 & 0.0 & 0.0 & 0.8 & 0.2 & 0.06 & 0.06 \\
\hline \multicolumn{10}{|c|}{ Croplands } \\
\hline BP & 3 & $1976-80$ & 0.1 & 3.5 & 0.1 & 4.2 & 1.7 & 0.06 & 0.06 \\
\hline HP & 3 & $1978-80$ & 0.0 & 0.3 & 0.1 & 3.3 & 1.2 & 0.08 & 0.07 \\
\hline RP & 4 & $1979-80$ & 0.0 & 0.5 & 0.1 & 1.8 & 0.5 & 0.06 & 0.06 \\
\hline RRP & 2 & $1979-80$ & 0.0 & 0.1 & 0.1 & 1.8 & 0.02 & 0.01 & 0.01 \\
\hline
\end{tabular}

Table 4. Mean annual amounts of rainfall, runoff and sediment discharge for watersheds.

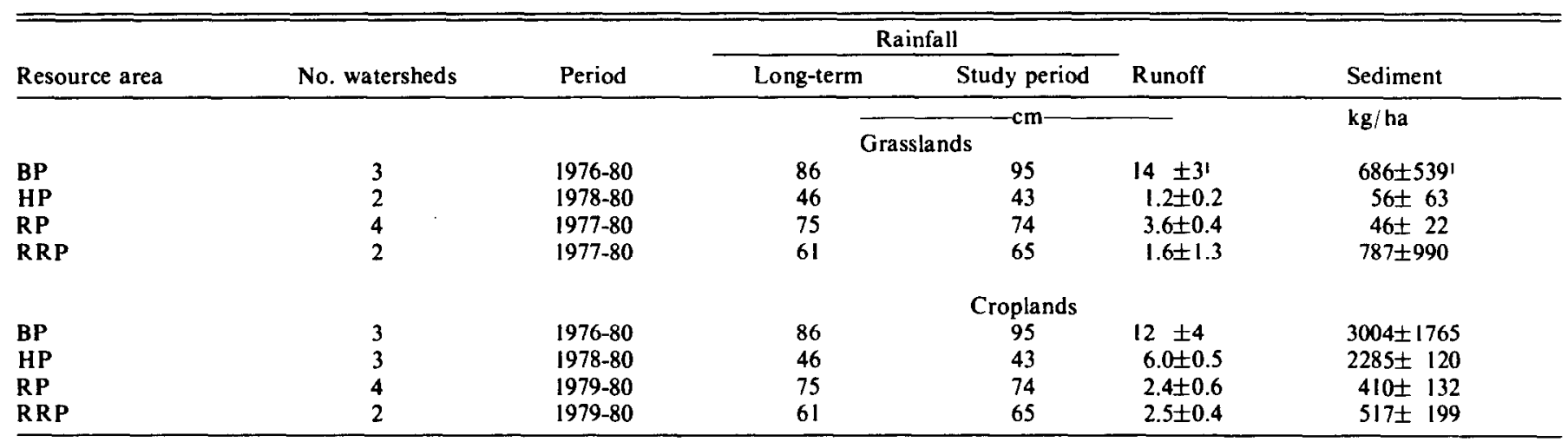

The \pm values represent single standard deviations of the means. 
Table 5. $\mathbf{N}$ received in annual rainfall!

\begin{tabular}{lcccc}
\hline \hline Resource area & $\mathrm{NO}_{3}^{-}-\mathrm{N}$ & $\mathrm{NH}_{4}^{+} \mathrm{N}$ & $\mathrm{NO}_{3}^{-} \mathrm{N}$ & $\mathrm{NH}_{4}^{+}-\mathrm{N}$ \\
\hline & \multicolumn{2}{c}{$-\mathrm{mg} / \mathrm{l}-$} & \multicolumn{2}{c}{$-\mathrm{kg} / \mathrm{ha}-$} \\
BP & 0.33 & 0.35 & 2.7 & 3.0 \\
HP & 0.46 & 1.20 & 1.9 & 5.0 \\
RP & 0.58 & 0.40 & 4.3 & 2.9 \\
R RP & 0.53 & 0.55 & 3.5 & 3.6 \\
\hline
\end{tabular}

$1 / 977-80$, average annual $\mathrm{N}$ values.

rients and sediment from the grasslands is considered slight. A similar case exists for the grasslands coverted to croplands, although subsequent nutrient discharge did increase. If a runoff storm occurs shortly after tillage, recommended fertilizer application, or a spring burn, temporarily high nutrient concentrations may result, but the concentrations tend to approach background levels within a few runoff events. Liberal fertilizer $P$ surfacebroadcast rates (e.g. $75 \mathrm{~kg} \mathrm{P/ha),} \mathrm{however,} \mathrm{may} \mathrm{extend} \mathrm{the}$ increased soluble $\mathbf{P}$ runoff concentrations for several months (Olness et al. 1980). In any case, magnitude of the annual nutrient losses tends to be very low, generally less than a $\mathrm{kg} /$ ha of nutrient. Surface runoff losses of more than $5 \%$ of an applied nutrient would be very rare. This has been the case in central Oklahoma even when surface runoff was 4 to 10 -fold greater than that observed in previous years (Olness et al. 1975).

In most cases, soluble $\mathrm{N}$ concentrations in runoff were well below recommended potable limits (i.e. 10 and $0.5 \mathrm{mg} / 1$, respectively, for nitrate- $\mathrm{N}$ and ammonium-N). Furthermore, the soluble $N$ concentrations in runoff were typically less than corresponding values in rainfall (Table 5). This means the wate rsheds act as a filter in removing soluble $\mathrm{N}$, and suggests there would be little point in trying to predict the soluble $N$ runoff losses on the basis of soil fertility characteristics.

Soluble $P$ concentrations in runoff were generally above the 0.01 mg/l "critical" level (Sawyer and McCarty 1967) suggested as sufficient for eutrophication of standing waters. This is true even for the ungrazed, virgin HP grasslands, indicating that such "critical" levels are a natural occurrence.

Recently, Sharpley et al. (1982) have been successful in predicting soluble $P$ losses from these watersheds using the following equation:

$$
\mathrm{Q}_{\mathrm{r}}=\mathrm{EXC} \times \mathrm{Q}_{\mathrm{s}} \times \mathbf{A}
$$

where $\mathrm{Q}_{\mathrm{r}}=$ soluble $\mathrm{P}, \mathrm{kg} / \mathrm{ha}$, in runoff, $\mathrm{EXC}=$ general extraction coefficient for soil $\mathrm{P}, \mathrm{Q}_{\mathrm{s}}=$ soluble $\mathrm{P}, \mathrm{kg} / \mathrm{ha}$, in top $\mathrm{l}-\mathrm{cm}$ of soil and $A=$ runoff a mount in $\mathrm{cm}$. They were also able to show (Sharpley et al. 1981) that soluble $P$ concentrations in runoff were an inverse exponential function of the respective sediment concentrations. Conscquently, accurate prediction of soluble P losses from Southern Plains grasslands seems feasible.

Both sediment N (TKN) and P(TP) losses were related quite well to sediment discharge. This is illustrated in Table 6 , where regression data are presented for a range of the watersheds. In the absence of this type information, Menzel (1980) has shown that an enrichment ratio (ER) procedure can be used as an alternative in predicting sediment $\mathbf{N}$ and $\mathbf{P}$ losses. In the case of $\mathbf{P}$, Sharpley et al. (1982) obtained good prediction of sediment $P$ losses from the
Table 7. Sediment discharge results obtained using the Modified Universal Soil Loss Equation.

\begin{tabular}{|c|c|c|c|c|}
\hline \multirow[b]{2}{*}{ Watershed } & \multicolumn{3}{|c|}{ Average sediment discharge/event } & \multirow[b]{2}{*}{$\mathbf{s}$} \\
\hline & Equation & Measured & $\mathbf{r}$ & \\
\hline \multicolumn{5}{|c|}{$-\mathrm{kg} / \mathrm{ha}-$} \\
\hline Y-14 (Kleingrass) & 29 & 23 & 0.94 & 1.31 \\
\hline $\begin{array}{l}\text { W-10 (Coastal } \\
\text { bermudagrass) }\end{array}$ & 169 & 152 & 0.95 & 1.09 \\
\hline $\begin{array}{l}\text { Y-8 (cot-sorg-oats } \\
\text { rot.) }\end{array}$ & 364 & 360 & 0.99 & 0.96 \\
\hline
\end{tabular}

$11976 / 77-1980$. Watershed Y-8 is described in Sharpley et al. (1982).

watersheds using total P content of the surface soil and ER's calculated from sediment discharge.

With regard to prediction of sediment discharge, preliminary results (Table 7) with the Modified Universal Soil Loss Equation (Williams 1975) are promising. This equation, which incorporates a runoff energy factor, allows prediction of sediment discharge on an event basis, a necessary feature for water quality modeling. In the equation:

$$
\mathrm{Y}=11.8\left(\mathrm{Qq}_{\mathrm{p}}\right)^{0.56} \mathrm{KCPSL}
$$

where $Y=$ sediment discharge in metric tons, $Q=$ runoff volume in $\mathrm{m}^{3}, \mathrm{q}_{\mathrm{p}}=$ peak runoff rate in $\mathrm{m}^{3} / \mathrm{sec}, \mathrm{K}=$ soil erodibility factor, $\mathrm{C}=$ crop management factor, $P=$ erosion control-practice factor and $\mathrm{SL}=$ slope length, gradient factor. A more detailed treatment regarding specific use and applicability of the above equation for the watersheds is in preparation.

\section{Conclusions}

Overall, the relatively short-term results (3-5 years) with these Southern Plains watersheds indicate nutrient and sediment discharge are posing no particular problems. We emphasize, however, that these short-term results should not be interpreted as indicative of the long-term situation. Nevertheless, the annual sediment discharges were all within tolerable limits. Less soluble $\mathbf{N}$ was in runoff than was received in rainfall. Of applied $\mathbf{N}$ and $P,<5 \%$ tended to be lost in runoff. However, runoff concentrations of the nutrients may be increased considerably (i.e. several fold) if runoff occurs shortly after fertilization or burning. The amounts and concentrations tend to decrease quickly, although the effect of $\mathbf{P}$ persists longer than that of $\mathrm{N}$. Preliminary results using predictive techniques to estimate nutrient and sediment discharge from the watersheds are encouraging.

\section{Literature Cited}

Doran, J.W., J.S. Schepers, and N.P. Swanson. 1981. Chemical and bacteriological quality of pasture runoff. J. Soil and Water Conserv. 36:166-171.

Golterman, H.L. and R.S. Clymo. 1969. Methods for chemical analysis of fresh water. Int. Biol. Programme. Blackwell Scientific Publ.

Kilmer, V.J. 1974. Nutrient losses from grasslands through leaching and runoff. p. 341-362 In; Forage Fertilization, D.A. Mays (ed.). Amer. Soc. Agron.

Menzel, R.G. 1980. Enrichment ratios for water quality modeling. p. 486-

\begin{tabular}{|c|c|c|c|c|c|c|}
\hline \multirow[b]{2}{*}{ Watershed } & \multicolumn{3}{|c|}{ TKN } & \multicolumn{3}{|c|}{ TP } \\
\hline & $\mathbf{r}$ & $\mathrm{s}$ & int & $r$ & $\mathbf{s}$ & int \\
\hline $\begin{array}{l}\text { SW-11 (Harding } \\
\text { wintergreen) }\end{array}$ & 0.88 & 0.0021 & 0.025 & 0.92 & 0.005 & 0.002 \\
\hline NG (blue grama) & 0.92 & 0.0008 & 0.078 & 0.97 & 0.005 & 0.009 \\
\hline Y-8 (cot-sorg-oats rot.) & 0.95 & 0.0011 & 0.318 & 0.94 & 0.003 & 0.053 \\
\hline
\end{tabular}

Table 6. Data from regression of sediment $N$ and $P$ on sediment discharge ${ }^{1}$.

11977-80. Watershed Y-8 is described in Sharpley et al. (1982). 
$492 \mathrm{ln}$ : "CREAMS-Field scale model for chemical, runoff and erosion from agricultural management systems." USDA-ARS Conserv. Res. Dep. 26.

Menzel, R.G., E.D. Rhoades, A.E. Olness, and S.J. Smith. 1978. Variability of annual nutrient and sediment discharges in runoff from Oklahoma cropland and rangeland. J. Environ. Qual. 7:401-406.

Neff, E.L. 1982. Chemical quality and sediment content of runoff water from southeastern Montana rangeland. J. Range Manage. 35:130-132.

Olness, A., S.J. Smith, E.D. Rhoades, and R.G. Menzel. 1975. Nutrient and sediment discharge from agricultural watersheds in Oklahoma. J. Environ. Q. 4:331-336.

Olness, A., E.D. Rhoades, S.J. Smith, and R.G. Menzel. 1980. Fertilizer nutrient losses from rangeland watersheds in central Oklahoma. J. Environ. Qual. 9:81-86.

Sawyer, C.N., and P.L. McCarty. 1967. Chemistry for sanitary engineers Second ed. McGraw-Hill Book Co., New York.

Sharpley, A.N., R.G. Menzel, S.J. Smith, E.D. Rhodes, and A.E. Olness. 1981. The sorption of soluble phosphorus by soil material during trans- port in runoff from cropped and grassed watersheds. J. Environ. Qual. 10:211-215.

Sharpley, A.N., S.J. Smith, and R.G. Menzel. 1982. Prediction of phosphorus losses in run off from Southern Plains Watersheds. J. Environ. Qual. 11:247-251.

Smith, S.J., P.B. Allen, and F.R. Schiebe. 1982. Acquisition and quality of watershed data from the Southern Plains Watershed and Water Quality Laboratory. p. 104-1 10. In; The Quality of Agricultural Research Service Watershed and Plot Data, USDA, ARM-W-31.

U.S. Department of Agriculture. 1965. Soil and water conservation needs-a national inventory. USDA Misc. Pub. 971. Washington, D.C.

U.S. Department of Interior. 1971. FWPCA methods for chemical a nalysis of water wastes. FCN 16020-7/71. Nat. Environ. Res. Center, Anal.Contr. Lab., Cincinnati, Ohio.

Williams, J.R. 1975. Sediment yield prediction with Universal equation using runoff energy factor. p. 244-252. In: "Present and Prospective Technology for Predicting Sediment Yields and Sources. ARS-S-40. USDA.

\section{To increase carrying capacity, improve forage quality and extend the pasture season, plant...}

\section{Perma-Pel Horse Pasture Seed Mix}

A special blend of tender, hardy grasses that are favored by horses and provide good protein forage and inexpensive TDN that saves on hay and grain costs. Grass seeds are selected for plants that grow good sod pastures, to reduce plant damage from trampling by horses with good pasture management. There are no clover seeds in this mix.

\section{Perma-Pel Cattle and Sheep Pasture Seed Mix}

A special blend with grasses, clovers and sub-clovers and other legume seeds to grow pastures that put efficient, economical weight gains on cattle and sheep. Special care is taken in this mix to add plants that reduce the danger of bloat, so long as a balanced grass population is maintained.
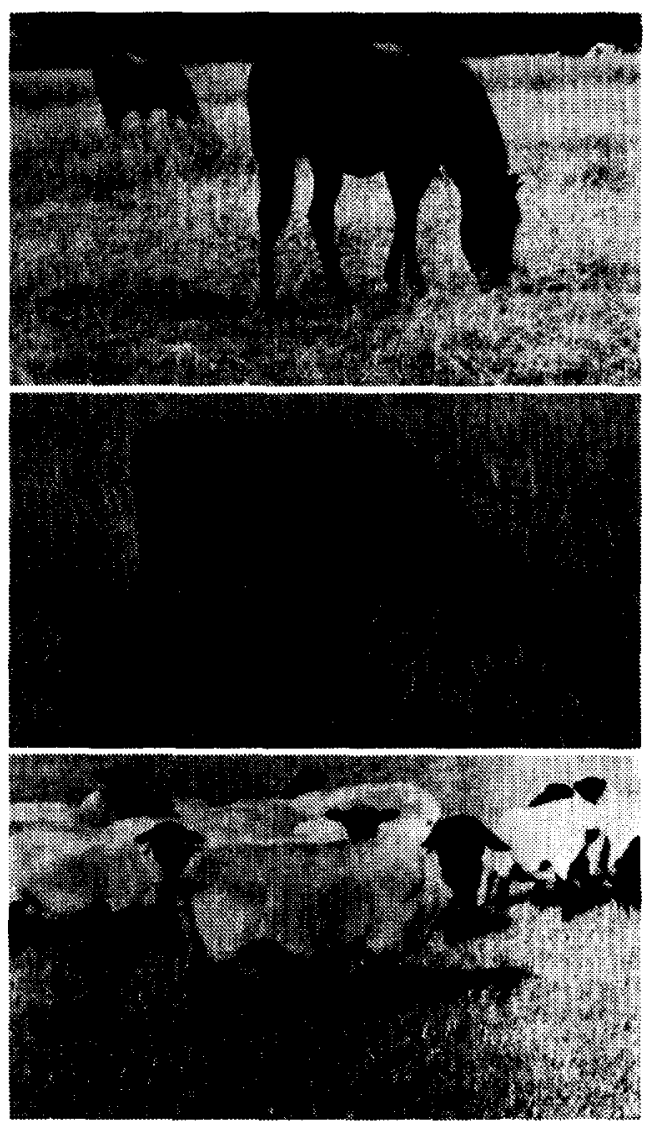

\section{One bag plants one acre.}

Perma-Pel Pasture Seed Mixes are conveniently packaged in bags designed for planting one acre. Both grass and legume seeds are coated with additives that enhance the microenvironment of the soil surrounding the seed and promote a high emergence rate. The extra weight of this coating also anchors the seed to the ground and camouflages the seeds to prevent loss from birds while awaiting germination. All legume seeds are also coated with Rhizo-Kote to innoculate the seed with rhizobia (soil bacteria) to assure proper nitrogen fixation of the legume plants.

Look for this special Perma-Pel Pasture Seed Mix at your local seed dealer.

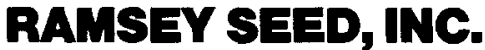
P.O. Box 352, Manteca, CA 95336 (209) 823-1721 